\title{
A Survey on Willingness to Provide Warning Information within A Company during Crisis
}

\author{
Bogdan Ćwik \\ Faculty of Logistics \\ Military University of Technology, Warsaw \\ Warsaw, Poland \\ e-mail: bogdan.cwik@wat.edu.pl
}

\begin{abstract}
This article presents results of surveys on willingness of the employees of Polish companies to providethe management with warning information on phenomena or occurrences that could cause a serious crisis or the company's collapse. It should be emphasised that the surveys were conducted in conditions of the financial markets stress and the employees were convinced that their companies were threatened or may have been faced with a crisis.
\end{abstract}

Keywords-early warning systems in companies; perception of risks; the concept of universal listening; warning information

\section{INTRODUCTION}

Economic troubles which took place on the financial markets in the years 2008-2010 has shown that economic processes can have an enormous destructive power and that the scale of this phenomenon can be both massive and unpredictable. The outburst of the crisis was unexpected and in the period prior to the outburst an optimistic sentiment had prevailed on the economic markets: financial, raw material, commodity and labour. It seemed that large numbers of experts were watching over the development of these markets. Only a few experts suggested that economic troubles ware likely to occur sooner or later. According to scientific publications and media commonly used methods of economic analyses were available and effective and systems of financial supervision were functioning properly. What is more, opinions of experts were fully accessible in media whereas research institutions were continuously developing theories, concepts and models. Scientists and experts were arguing that the reliability of numerous types of existing models of early warning had been proved by surveys and the market practise. During this period the author of this article was able to conduct a few unique surveys among the employees of Polish companies. One of these surveys was the survey on willingness of the employees of Polish companies to provide the management with warning information on phenomena and occurrences that could cause a serious crisis or the company's collapse. It should be emphasised that the surveys were conducted in conditions of the financial markets stress and the employees were convinced that their companies were threatened or may have been faced with a crisis.

\section{THE CHARACTERISTICS OF A PROBLEM}

Five main stages of the development of a crisis in a company can be distinguished as follows:

- blindness,

- inactivity,

- mistakes,

- crisis,

- destruction, collapse.

The first of these stages is especially important as its main characteristic is the lack of awareness of the impending risk. The ability to identify warning signals plays a major role at this stage. This ability creates also the greatest opportunities for improvement of the effectivity of warning systems. The outburst of a crisis is usually connected with:

- astonishment,

- information deficit,

- delayed response,

- growing number of uncertain future events,

- loss of control over the situation,

- threat to an important interests,

- arousing emotions,

- collective panic.

Usually after the outburst of a crisis following questions may be asked: What was the reason for it? Why the warning methods and especially the early warning systems have failed? Why the risk management has failed? Moreover, after some time it is usually said that the symptoms of an impending crisis were clearly visible before the event.

According to surveys and analyses the human factor is the main cause of risks as well as disruptions and distortions in the process of identifying warning signals. Human decisions, choices and limitations cause many mistakes. Humane attitudes, behaviours, emotions, desires and motivations are individually negligible but in groups measured in millions such factors could have an enormous negative influence. That is why they should be researched more extensively.

The perception of threat is a common natural process which includes warning signals at the molecular level as well as warning signals in the plant world and in the animal world [1]. The problem of signal perception and conveyance by humans was described among others by Philip G. 
Zimbardo who wrote: "every man lives in its own world. This world was built as a result of multiple receiving, filtering, organising and interpreting of the vast number of stimuluses from his surroundings [...]. The world of information received by one human being is different from the world of an another person. This discrepancy is a result of a complicated perception process (which depends on the receptors and brain activity) and other factors which have influence on an individual such as personality, motivation, education and experiences" [2].

In times of crisis it is important to convey information on the impending risk quickly and effectively. Solutions of the problem of identifying risks were summarised among others in the following concepts: vigilance [3], universal listening [4], and in methods of the business environment monitoring such as the environmental scanning system [5] and the business intelligence tracking system [6]. These methods are complemented by the theory of weak signals described for the first time by Igor $\mathrm{H}$. Ansoff [7] and developed by Elinę Hiltunen [8], Humbert Lesca and Nicolas Lesca [9]. This theory covers flexible, adaptive and resistant to non-heterogenous information interpreting of warning signals, which includes the so called tactic knowledge. The concept of peripheral vision [10] and the concept of competitive intelligence [11] were also based on the theory of weak signals.

The above mentioned concepts are characterised by selforganisation, creativity, the strategy of vigils and continuous listening which include:

- penetrating observation and creative listening to the external and internal environment;

- creative management, flexibility and adaptation;

- creative processing of data and anticipation of values and situations which pose a threat of collapse (bankruptcy), responding ahead of events.

While tacking the problem of an effective identification of weak signals, conclusions and mechanisms described by the theory of attention could be useful. Careful and undivided attention is a synonym of vigilance which is understood as readiness for detection, recognition and reaction to minor and almost invisible random changes in the environment over a longer period of time. Attention is called the activator of the perception information. Attention systems enables the body: to perceive only a part of stimuluses which are reaching the senses of the perceiver, to bring back only a part of information encoded in the memory, to activate only a part of possible thinking processes. Particular mechanisms of attention are explained primarily by different models. The basic models include: filter of attention, resources of attention, extended concentration (vigilance), detection of signals, priming and flip-flop. These models together with researches on which they were based are described among others in papers of Daniel Kahneman [12], Donald E. Broadbent [13], Addie Johnson and Robert W. Proctor [14], Jeremy Wolfe and Lynn Robertson [15], Bruce E. Goldstein [16], Glyn W. Humphreys, John Duncan and Anne Treisman [17], Donald A. Norman [18]; Gerald Matthews, Peter H. Lindsay and Donald A. Norman [19].
Effectiveness of the above solutions and concepts depends on the involvement, mutual conveyance of signals, openness to news streams, creative listening to the environment, sense of responsibility and willingness to put in an effort for common good.

Events on the financial markets in the years 2008-2010 and the economic standing of many companies at that time have created perfect conditions to verify usefulness of the above concepts of warning systems in Polish companies which took part in the surveys.

\section{METHODOLOGY AND THE RESEARCH ENVIRONMENT}

The surveys were conducted during the period from the autumn of 2008 to December 2009. In this period the situation on the economic markets was serious. Media were informing on a daily basis about bankruptcy of companies and banks. The stock exchange indexes were slumping heavily. It was the period of the mounting crisis on the global financial markets during which the Polish currency was weakening severely (the exchange rate PLM/EUR exceeded 4.70). Media and companies were govern by the mood of uncertainty. The WIG20 stock index fell below 1500 points (which was the lowest level in six years) and its daily changes exceeded $2 \%$.

Companies form various sectors took part in these surveys. The group was predominated by medium and small companies which employed up to 1000 workers. The vast majority of these companies fell into the category of small and medium-sized enterprises. 172 companies from all over Poland were researched. The survey consisted in the disclosure of the financial statements for the year of 2008 and surveys on the perception on risks which were conducted among the employees of these companies. The financial position of the majority of the researched companies was difficult. In the attachments to the financial statements titled "Additional information" the management of 148 companies (86\%) indicated a risk of the outburst of a crisis which was confirmed by researches conducted by means of discriminative models of early warnings against a bankruptcy. Researchers used 32 models that had been developed by Polish authors and the Edward I. Altman's ZETA model together with his recommendations presented in "Bankruptcy, credit risk, and high yield junk bonds" [20]. $89.8 \%$ of results indicated that the companies were threatened by the risk of bankruptcy. At the same time, 256 out of 283 employees $(91.1 \%)$ claimed in the survey that their companies were hit by the crisis. Only 25 employees $(8.9 \%)$ claimed that their companies were not facing any difficulties.

The research initially called "A survey on reactions to bad news" which is the main subject of this article was conducted in the above circumstances. Willingness of employees at the various levels of hierarchy to convey information on occurrences and phenomena which may pose a threat to the functioning of a company or even lead to its bankruptcy was researched. The aim of the study was to verify the following main thesis: "In companies there are collective warning systems, a main characteristics of which are vigilance and reediness to cooperate in reading and 
conveying signals of serious threats to the company, and all employees plays an important role in these systems".

The main thesis was complemented by two other theses:

T1 - 90\% of employees is characterized by vigilance and willingness to convey warning signals to the management.

$\mathrm{T} 2-90 \%$ of employees in times of crisis is ready to make an additional effort in order to deal with the crisis in their company.

The above theses were verified by means of a fraction test of a large sample and a chi-squared test with variables at a nominal scale. The fraction test was conducted in accordance with the following formula:

$$
z=\frac{\hat{p}-p_{0}}{\sqrt{\frac{p_{0} q_{0}}{n}}}
$$

where: $\hat{\mathrm{p}}-$ the actual frequency

$\mathrm{p}_{\mathrm{o}}$-the theoretical frequency

$\mathrm{q}_{\mathrm{o}}=1-\mathrm{p}_{\mathrm{o}}$

whereas the chi-squared test:

$\chi^{2}=\sum \frac{(O-T)^{2}}{T}$

where: $\mathrm{O}$ - the theoretical quantity

$\mathrm{T}$ - the actual quantity

Tests were carried out on the significance level $\alpha=0,05$.

In the survey the electronic data collection questionnaire was used. Participants (employees of finance departments, managers and other regular employees) had to respond to the following questions on the indicated website.

- Let's assume that you have a piece of information on an occurrence or a phenomenon which may lead to a crisis or even a bankruptcy of your company. How the management (the board or the manager) would react? Which of the following answers come closest to describing your opinion?

a) They do not want to know anything about it, they could even ridicule the supplier of the information.

b) They would deem my advice to be hasty and view it as grumbling.

c) They would say that they have already know about it but they would do nothing anyway.

d) They would start a conversation in order to explain this issue and encaurage me to express my opinion.

e) They would react immidiately.

f) I do not know.

- Let's assume that you have a piece of information on an occurrence or a phenomenon which may lead to a crisis or even a bankruptcy of your company. How would you feel in such a situation? Which of the following answers come closest to describing your opinion?

a) I will keep the information just for myself, it is none of my bussiness.

b) I will keep the information just for myself because they would ridicule me or they would resent me.

c) I will inform the management but they would not do antything about it. d) I will inform the management but I will not make any additional effort.

e) I will inform the management and I will activelly support them.

f) I do not know.

- Let's assume that you found out that your company is close to a bankruptcy. How would you feel in such a situation?Which of the following answers come closest to describing your opinion?

a) I will start looking for a job.

b) I will wait to see how the situation will develop.

c) I will agree to reduce my payment in order to save the comapny.

d) I will make an additional effort in order to save the company.

e) I do not know.

\section{THE FINDINGS OF THE SURVEYS}

Answers to the first question (Table 1) show that $36 \%$ of the employees were convinced that the management would not react or would react negatively to the information disclosed by an employee that the company is exposed to a threat. Only $57 \%$ of employees claimed that the management would react positively to the information that the company is exposed to a threat.

TABLE I. EXPECTED REACTIONS OF THE MANAGEMENT TOTHE INFORMATION ABOUT A SERIOUS THREAT TOTHE COMPANY

\begin{tabular}{|l|c|c|}
\hline \multicolumn{1}{|c|}{$\begin{array}{c}\text { Expected reactions of the } \\
\text { management }\end{array}$} & $\begin{array}{c}\text { The number of } \\
\text { observations }\end{array}$ & Percentage \\
\hline $\begin{array}{l}\text { They do not want to know } \\
\text { anything about it, they could even } \\
\text { ridicule the supplier of the } \\
\text { information. }\end{array}$ & 7 & $4 \%$ \\
\hline $\begin{array}{l}\text { They would deem the employye's } \\
\text { advice to be hasty and view it as } \\
\text { grumbling. }\end{array}$ & 19 & $11 \%$ \\
\hline $\begin{array}{l}\text { They would say that they have } \\
\text { already know about it but they } \\
\text { would do nothing anyway. }\end{array}$ & 36 & $21 \%$ \\
\hline $\begin{array}{l}\text { They would start a conversation } \\
\text { in order to explain this issue and } \\
\text { encaurage the employee to } \\
\text { express his opinion. }\end{array}$ & 62 & $36 \%$ \\
\hline They would react immidiately. & 36 & $21 \%$ \\
\hline I do not know. & 12 & $7 \%$ \\
\hline
\end{tabular}

Source: author's own elaboration

The aim of the second question was to verify the thesis T1. According to the answers (Table 2) only $73 \%$ of participants declared that in the case of obtaining a piece of information that the company is exposed to a threat they would inform the management. However, only $25 \%$ of participants were willing to actively support the company.

In the light of the findings the statistical fraction test on the significance level $\alpha=0,05, \mathrm{Z}_{\mathrm{kr}}=1,96$, the value of the statistic $\mathrm{z}=5,02$, thus $\mathrm{z}>\mathrm{Z}_{\mathrm{kr}}$, indicates that the thesis $\mathrm{T} 1$ should be refuted. Also the chi-squared test on the significance level $\alpha=0,05, \chi_{k r}^{2}=3,84$, the value of the 
statistic $\chi^{2}=5,43$, thus $\chi^{2}>\chi_{k r}^{2}$, indicates that the thesis $\mathrm{T} 1$ should be refuted.

TABLE II. WILLINGNESS OF THE EMPLOYEES TO PROVIDE INFORMATION ABOUT A SERIOUS THREAT TOTHE COMPANY

\begin{tabular}{|c|c|c|}
\hline Willingness of the employees & $\begin{array}{c}\text { The number of } \\
\text { observations }\end{array}$ & Percentage \\
\hline $\begin{array}{c}\text { I will keep the information just } \\
\text { for myself, it is none of my } \\
\text { bussiness. }\end{array}$ & 15 & $9 \%$ \\
\hline $\begin{array}{c}\text { I will keep the information just } \\
\text { for myself because they would } \\
\text { ridicule me or they would resent } \\
\text { me. }\end{array}$ & 9 & $5 \%$ \\
\hline $\begin{array}{c}\text { I will inform the management but } \\
\text { they would not do antything } \\
\text { about it. }\end{array}$ & 34 & $20 \%$ \\
\hline $\begin{array}{c}\text { I will inform the management but } \\
\text { I will not make any additional } \\
\text { effort. }\end{array}$ & 49 & $28 \%$ \\
\hline $\begin{array}{c}\text { I will inform the management } \\
\text { and I will activelly support them. }\end{array}$ & 43 & $25 \%$ \\
\hline I do not know. & 22 & $13 \%$ \\
\hline
\end{tabular}

Source: author's own elaboration

On the basis of the findings it may be stated that the thesis T1 according to which $90 \%$ of employees are willing to provide the management with the information on a serious threat to the company should be refuted.

The aim of the third question was to verify the thesis $\mathrm{T} 2$. In accordance with the answers (Table 3) 59\% of the employees declared that in the case of obtaining a piece of information that the company is close to a bankruptcy they would start looking for a new job. Only $2 \%$ was willing to agree to the reduction of payments in order to improve the financial standing of the company. The above answers have proved that in the case of serious economic troubles the employees will not identify themselves with the company's problems. What is more, $21 \%$ of participants claimed that they would remain inactive in anticipation of the development of the company's situation. Only $16 \%$ was willing to put in an additional effort in order to save the company.

TABLE III. WILLINGNESS OF THE EMPLOYEES TO HELP SAVE THE COMPANY

\begin{tabular}{|l|c|c|}
\hline \multicolumn{1}{|c|}{ Willingness of the employees } & $\begin{array}{c}\text { The number } \\
\text { of } \\
\text { observations }\end{array}$ & Percentage \\
\hline I will start looking for a job. & 101 & $59 \%$ \\
\hline $\begin{array}{l}\text { I will wait to see how the situation } \\
\text { will develop. }\end{array}$ & 36 & $21 \%$ \\
\hline $\begin{array}{l}\text { I will agree to reduce my payment in } \\
\text { order to save the company. }\end{array}$ & 3 & $2 \%$ \\
\hline $\begin{array}{l}\text { I will make an additional effort in } \\
\text { order to save the company. }\end{array}$ & 28 & $16 \%$ \\
\hline I do not know. & 4 & $2 \%$ \\
\hline
\end{tabular}

Source: author's own elaboration

In the light of the findings the statistical fraction test on the significance level $\alpha=0,05, \quad \mathrm{z}_{\mathrm{kr}}=1,96$ the value of the statistic $\mathrm{z}=24,58$, thus $\mathrm{z}>\mathrm{z}_{\mathrm{kr}}$, indicates that the thesis $\mathrm{T} 2$ should be refuted. Also the chi-squared test on the significance level $\alpha=0,05, \chi_{k r}^{2}=3,84$, the value of the statistic, $\chi^{2}=99,9$ thus $\chi^{2}>\chi_{k r}^{2}$, indicates that the thesis $\mathrm{T} 2$ should be refuted.

On the basis of the findings it may be stated that the thesis $\mathrm{T} 2$ according to which $90 \%$ of employees are willing to put in an additional effort in order to overcome a crisis in the company should be refuted.

\section{CONCLUSION}

The findings of the survey indicate that the transfer of negative information as well as warnings in Polish companies may face various barriers and is not $90 \%$ effective. Hence, the main thesis that in companies there are collective warning systems, a main characteristics of which are vigilance and reediness to cooperate in reading and conveying signals of serious threats to the company, and all employees plays an important role in these systems should be refuted.

Attitudes of the respondents has shown that developed in literature concepts of the effective early warning against a company's bankruptcy which are based on vigilance, universal listening or attention theories are not $100 \%$ effective in Polish companies. It may also be stated that the above phenomenon has negatively contributed to the effect of astonishment in the process of interpreting warning signals as well as to the downgrading the reliability and effectiveness of early warning systems which are based on the above mentioned concepts.

\section{REFERENCES}

[1] L. Impelluso, Natura i jej symbole: rośliny i zwierzęta, Wydawnictwo Arkady, Warsaw 2006.

[2] P. G. Zimbardo, Psychology and life, 2010.

[3] H. Lesca \& N. Lesca, Weak signals for strategic intelligence: anticipation tool for managers, John Wiley \& Sons, Inc., London 2011.

[4] G. Nizard, Métamorphoses de l'enterprise, 1991.

[5] R. M. Narchal \& K. Kittapa \& P. Bhattacharya, "An environmental scanning system for business planning", Long Range Planning, Vol. 20/6, nº6, December 1987, p. 96-105.

[6] C. W. Choo, "Environmental scanning as information seeking and organizational learning", Information Research, 7(1), 2001.

[7] H. AnsoffI, "Managing Strategie Surprise by Response to Weak Signals", California Management Review, 1975, vol. 18, No 2.

[8] Hiltunen E., Weak Signals in Organizational Futures Learnig, Aalto University School of Economics, Aalto Print, Aalto 2010.

[9] H. Lesca \& N. Lesca, Weak signals for strategic intelligence: anticipation tool for managers, John Wiley \& Sons, Inc., London 2011.

[10] G. S. Day \& P. J. H. Schoemaker, Peripherial Vison: Detecting the Weak Signals That Will Make or Break Your Company, Harvard Business School Press, Cambridge 2006.

[11] B. Gilad, Early warning: Using Competitive Intelligence to Anticipate Market Shift s, Control Risk, and Create Powerful Strategies, AMACOM, New York 2003.

[12] Kahneman D., Attention and effort, Prentice-Hall inc., Englewood Cliffs, New Jersey 1973.

[13] Broadbent D. E., Perception and communication, Oxford University Press, Oxford 1987. 
[14] A. Johnson \& R. W. Proctor, Attention: theory and practice, Sage Publications, Thousand Oaks, Calif. 2004.

[15] J. Wolfe \& L. Robertson, From perception to consciousness: searching with Anne Treisman, Oxford University Press, Oxford; New York, NY 2012.

[16] E. B. Goldstein, Sensation and perception, Brooks/Cole Pub., Pacific Grove, CA, 1996.

[17] G. W. Humphreys\&J. Duncan, A. Treisman, Attention, space, and action: studies in cognitive neuroscience, Oxford University Press, Oxford; New York 1999.
[18] D. A. Norman, Memory and Attention, An Introduction to Human Information Processing, John Wiley \& Sons, Inc. New York, London -Sydney, Toronto, 1976.

[19] P. H. Lindsay \& D. A. Norman, Human information processing : an introduction to psychology, 1971.

[20] E. I. Altman, Bankruptcy, credit risk, and high yield junk bonds, Blackwell Publishers, Malden, MA 2002. 